\title{
Contending with Complexity: The Role of Evaluation in Implementing Sustainable Natural Resource Management
}

\author{
Boru Douthwaite ${ }^{1}$, Robert Delve ${ }^{2}$, Javier Ekboir ${ }^{3}$ and Steve Twomlow ${ }^{4}$ \\ ${ }^{1}$ International Center for Tropical Agriculture (CIAT), Cali, Colombia; ${ }^{2}$ Soil Fertility Management, Tropical Soil Biology \\ and Fertility (TSBF) Institute of CIAT, Kampala, Uganda; ${ }^{3}$ The International Maize and Wheat Improvement Center \\ (CIMMYT), Mexico; ${ }^{4}$ Soil and Agrobiodiversity for Ecosystem Health, International Crop Research Institute for the \\ Semi-Arid Tropics (ICRISAT), Bulawayo, Zimbabwe
}

\begin{abstract}
Three case studies show that natural resource management (NRM) research aimed at sustainably improving the well-being of African small-holder farmers is complex, and that monitoring and evaluation (M\&E) is an essential tool in coping with this complexity, supported by an 'innovation systems' view of the adoption process. In the case studies, researchers adjusted their activities and outputs on the basis of learning from M\&E. Many of the insights came through identifying farmer innovations, which also proved a source of improvements to the respective technologies. Together, better understanding and iterative improvements made eventual widespread impact more likely. Farmers also learnt from M\&E exercises and this learning facilitated adoption. The understanding of the early adoption process provided by M\&E can provide a foundation for more plausible impact assessment.
\end{abstract}

Keywords Africa; impact assessment; innovation systems; participatory research approaches

\section{Introduction}

The Consultative Group on International Agricultural Research (CGIAR) system was founded in 1971 and is now made up of 16 agricultural research centres around the world with the following mission:

To contribute to food security and poverty eradication in developing countries through research, partnerships, capacity building, and policy support, promoting sustainable agricultural development based on the environmentally sound management of natural resources. (http:/ / www.cgiar.org/who/index.html)

The CGIAR system has been most successful in breeding improved crop varieties that helped catalyse the Green Revolution. This research was based on a linear view of the innovation process, called Transfer of Technology (TOT), in which new technologies are developed in CGIAR centres, passed to counterparts in National Agricultural Research and Extension Systems (NARES) who might carry out some local adaptation, before being passed on to the farmer as a 'finished' product (Chambers \& Jiggins, 1986; Ruthenberg, 1985). In this model farmers either adopt or reject. They do not carry out any significant local adaptation, and are not seen as sources of innovation in their own right (Rogers, 1995). The model worked delivering a technology that was simple for farmers to understand and use - improved germplasm - into relatively simple irrigated farming systems but has been less successful introducing NRM technologies into the same environments (Douthwaite et al., 2001a).

It is now well accepted that simple, linear innovation models, such as TOT, are not adequate, particularly for natural resource management aimed at improving the well-being of poor farmers in developing countries (Biggs, 1989; Clark, 1995; Douthwaite, 2002). This is because the linear view of science does not model the complexity of the systems in which small-scale producers operate and the inherent complexity of most natural resource management technologies. Small-holder farming systems tend to be complex because crop production, for example, is usually only a small part of a broad livelihood portfolio that may encompass a wide variety of off-farm activities, the gathering of forest products, the raising of livestock, etc. Also, the farming systems of poor people in the tropics are subject to a multitude of exogenous influences, such as highly variable 
rainfall, especially in semi-arid areas, and a constantly changing economic climate with resulting swings in input costs and market prices, dynamic land use changes, and various other episodic events (Sayer \& Campbell, 2001). In short, the complexity in which small-holder farmers operate means that technologies developed and promoted using the simplistic TOT view of the innovation process are unlikely to be adopted.

Sayer and Campbell (2001) state that sustained improvements to the livelihoods of poor tropical farmers requires a different type of research, the objective of which is to enhance the capacity of rural people to adapt to changing conditions, rather than to deliver 'finished' technologies. They identify participatory approaches and monitoring and evaluation (M\&E) as crucial to support the 'learning by doing' and other types of learning necessary for enhanced adaptive capacity. However, although CGIAR scientists have been developing participatory approaches since the early 1980s (e.g., Rhoades \& Booth, 1982), they are still by no means mainstream (Probst, 2002). CGIAR research methods remain largely scientist controlled with little adaptation to farmer feedback during the course of research. Moreover, evaluation in the CGIAR system is still commonly focused on predicting outcomes (ex ante impact assessment) or measuring impacts (ex post impact assessment) (Alston et al., 1995) and little work has been done on institutionalising M\&E (Ekboir, forthcoming; Horton, 1998). Indeed, impact assessment in the CGIAR remains grounded in traditional agricultural economics (Horton, 1998) that relies on establishing a linear causal relationship between the costs and benefits of research, and then attempting separately to attribute impact to the different successful components. Such approaches are often invalid for NRM research because such linear relationships generally do not exist in complex systems (Ekboir, forthcoming; Sayer \& Campbell, 2001).

In the rest of the paper we present three case studies of participatory NRM research carried out by three CGIAR centres. Our objective is to assess the extent to which M\&E allowed the research projects to cope with complexity through bringing about learning and change. We then follow with a discussion of how inclusion of M\&E can build the foundation for more plausible ex post impact assessment. In the case studies we consider M\&E to include the different information gathering and sharing activities that take place during the research processes.

\section{Case Studies of M\&E in Participatory Research Carried Out by CGIAR Centres}

\section{Theory of the case}

Case studies require focus otherwise they can become too long and present irrelevant data. One device for assisting focus is to employ a 'theory of the case' (Sechrest et al., 1996). The theory of the case used in this paper is that all three case studies described in this section implicitly assume the 'learning selection' conceptual map of the technology development and adoption process (Douthwaite et al., 2002) shown in Figure 1. This conceptual map is based on the 'innovation systems' view of the innovation process (Nelson, 1993; OECD, 1999), which sees innovation being produced by networks of actors that co-evolve with the technologies they generate (Rycroft \& Kash, 1999). The co-evolution occurs as a result of iterative experiential learning between the actors involved (Rosenberg, 1982) that is intrinsically random (Kaufmann, 1995). Successful innovations result from strong interactions and knowledge flows within these networks.

The learning selection model recognises four phases in the innovation process:

- Development phase: Innovators (e.g. researchers, farmers, input suppliers or other agents working together or in isolation) are permanently searching for new technological, economic, institutional or social alternatives to achieve their objectives (which may include improved livelihoods for farmers or professional recognition for researchers). Problem diagnosis with the intended target group(s) is part of this process. When an alternative is identified, the innovators develop 'best bet' integrated solutions.

- Start-up phase: The network of early developers take these 'best bet' options and demonstrate them to individual and/or a network of farmers, in the hope that farmers will see that at least some aspects hold out a 'plausible promise' of benefiting them, sufficient to 


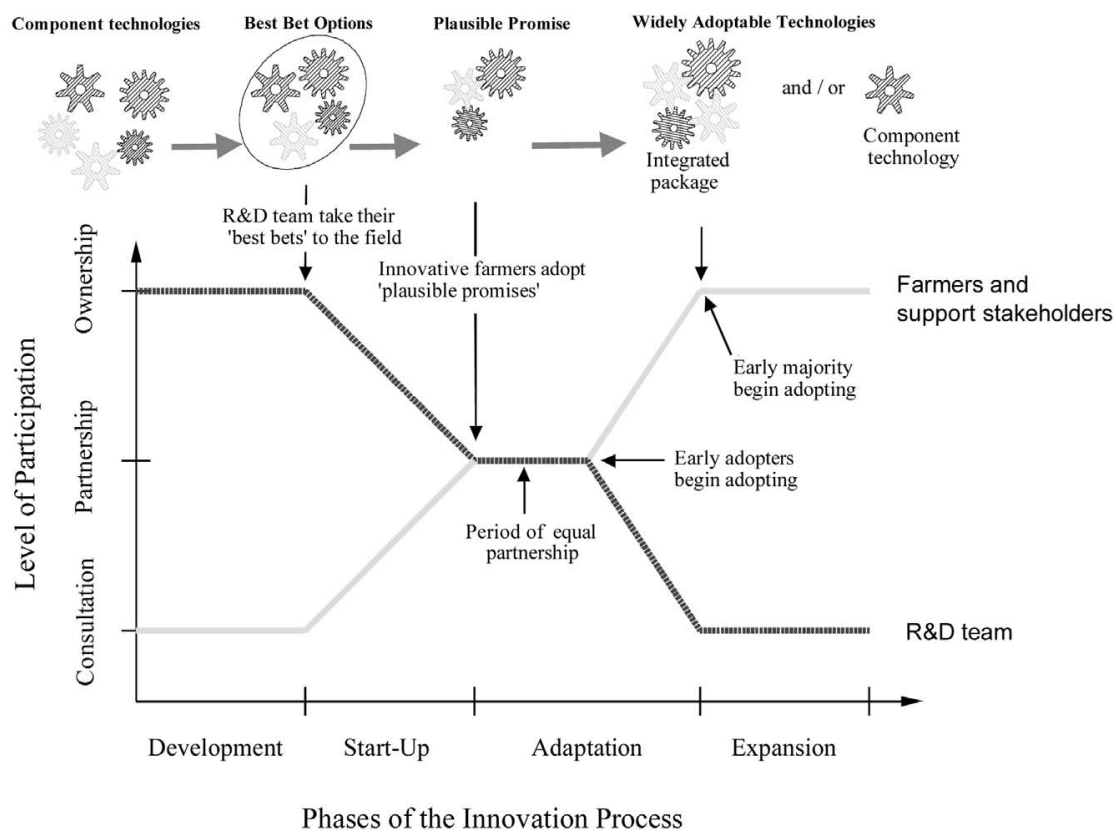

Figure 1 The 'learning selection' conceptual map of the innovation process adopted in the case studies (adapted from Douthwaite et al., 2002)

motivate at least a few to contribute their own time and land in experimenting.

- Adaptation phase: Experimenting farmers and other agents work together to co-evolve the 'plausible promise' into something better; something that is seen to work and make sense to the wider community.

- Expansion phase: Adoption levels expand as the community begins to adopt their locally constructed solution(s). This might be an integrated package and/or a single component of the 'best bet' options originally introduced. Implicit to this conceptual map is the premise that once developed, a complex technology that is widely adopted in a pilot site, will scale-out to other, similar, communities through multi-actor interactions. However, scaling-out can be accelerated by a properly designed extension approach that speeds up both the knowledge spread and the experiential learning that is necessary to construct the technology in communities elsewhere.

\section{TSBF-CIAT: Farmer Participatory Evaluation of Legume Cover Crop and Biomass Transfer Technologies for Soil Fertility Improvement in Eastern Uganda}

\section{Introduction}

The development phase of this project began in late 1998 when a participatory diagnosis identified soil fertility as one of the main constraints to agricultural productivity in eastern Uganda. As a result the Tropical Soil Biology and Fertility Institute of the International Center for Tropical Agriculture (TSBF-CIAT) began looking for solutions with 11 other stakeholders, comprising of Makerere University, National Agricultural Research Organisation, the International Forestry Centre (ICRAF), Appropriate Technology (Uganda), Department of Agriculture, Uganda National Farmers Association (UNFA), Food Security and Export Marketing project (FOSEM), Africa 2000 Network (A2N), Sasakawa Global 2000 (SG2000), farmers, the District Agricultural Extension and the local administration. Much research on legume cover crops has been carried out in Africa over the past 70 years, and although there had been little real adoption (Sumberg, 2002) in Africa, the stakeholders involved felt that using participatory methodology to offer farmers choices of different legumes offered the best prospects for solutions to the problem. TSBF began the start-up phase by introducing 'bestbet' legume cover crop (LCC) and shrub species into two sub-counties of Tororo District, in east- 
ern Uganda. In some treatments there was biomass transfer (BT) of legume material from one field to another. Several trials were established, together with 40 participating farmers, backstopped by field officers employed by the project and from the government's district extension services. The purpose of the trials was to validate and demonstrate the effectiveness of the LCCs and shrubs at improving soil fertility and controlling weeds. The legume species were: Canavalia ensiformis, Crotalaria grahamiana, Dolichos lablab, Mucuna pruriens, Tephrosia vogellii and Tithonia diversifolia.

\section{Materials and methods}

TSBF-CIAT conducted a farmer participatory evaluation of the LCC and BT species after seven seasons from December 2001 to January 2002 with 21 farmer groups, representing 234 farmers (92 male, 142 female). The farmer groups were purposively selected on the basis of having several seasons' experience with the legumes. Group discussions and key informant interviews were then held to:

- Establish farmers' assessment of the legume species for soil fertility improvement.

- Identify farmer innovations with respect to the use and management of the legumes.

- Identify farmers' evaluation criteria when comparing between legumes.

- Conduct a matrix ranking based on these criteria.

\section{Results and discussion}

One of the main findings from the M\&E of this work was the high degree of knowledge that farmers already had of the legumes, which showed up when farmers were asked to identify positive and negative characteristics (Table 1). Other evidence of existing knowledge was the names some farmers gave to some of the legumes. For example, one group called Canavalia 'Yathipendi', meaning 'medicine for banana' while another group, dominated by old men, identified it as 'Akengu ka Angu' meaning 'trap for the hyena'. Tephrosia was locally known as 'Yathi fuuko' (medicine for mole rat) or 'Yathirechi' (medicine for fish).

The M\&E also found that farmers were attempting to find uses for the legumes beyond improving soil fertility and suppressing weeds, or attempting to reduce the cropland occupied by legumes (Table 2). Some of this innovation occurred as a result of the trial, although the $M \& E$ did not differentiate between 'old' and 'new' discovery. A significant result of the trials was to encourage farmers to place more emphasis on their existing knowledge, and build on it.

Farmers were asked to make explicit the criteria they used when evaluating the legumes (Table 3). Nine criteria were listed by farmers which were categorized under three headings, inputs (labour, establishment ease), outputs (crop, soil, weed control, biomass), and other uses (intercropping and multiple uses). The overall farmer ranking, developed using a ranking analysis tool with the 21 groups, is shown in Table 4 . The rank order from the most to the least preferred was Mucuna, Tithonia, Canavalia, Crotalaria, Lablab and Tephrosia.

The project initiated a range of approaches to move from the adaptation to the expansion phase. These included: training extension agents on the use and management of the technology; identifying and training innovative farmers in each sub-county; and providing support to farmer-to-farmer extension. Particular attention was paid to the latter with the organisation of many study and exchange tours to enhance farmer-to-farmer learning and adoption of the technologies promoted. By the end of 2001, over 2000 farmers had established their own evaluation trials as a result of extension visits, farmer-trainer visits and exchange visits to demonstrations sites.

Discussions with farmers during the group assessments and ranking exercises, as well as open and probing questions, gave insights into the constraints to farmer adoption. Fallowing the land is not possible where small land sizes or high population densities exist and where seed supply for these legume cover crops is poor. Farmers commonly cite difficulties in finding the labour required for collecting or incorporating biomass. Also, many farmers were very reluctant to use land and labour without producing a crop, even if future benefit justifies the investment. This is because most farmers' main priority is food production, and they are very risk adverse. As a participating farmer commented, 'Its better to have even one gorogoro tin of maize [from a depleted field that was planted with maize] than to be guaranteed no maize at all this season by planting a 
Table 1 Farmers' assessment of the legume species

\begin{tabular}{|c|c|c|}
\hline LCC/shrub & Positive aspects & Negative aspects \\
\hline $\begin{array}{l}\text { Mucuna } \\
\text { Local name: none }\end{array}$ & $\begin{array}{l}\text { - Improves soil fertility } \\
\text { - Suppress weeds effectively } \\
\text { - Produces high biomass } \\
\text { - Quick maturing }\end{array}$ & $\begin{array}{l}\text { - Not edible } \\
\text { - Not good for intercropping } \\
\text { (climbs the crops) } \\
\text { - Requires high labour for clearing } \\
\text { and incorporation } \\
\text { - Can harbour snakes and wild } \\
\text { cats if planted near the home }\end{array}$ \\
\hline $\begin{array}{l}\text { Canavalia } \\
\text { Local name: Yathipendi } \\
\text { (medicine for banana) or } \\
\text { Akengu ka angu (trap for the } \\
\text { hyena) }\end{array}$ & $\begin{array}{l}\text { - Improves soil fertility } \\
\text { - Has fodder value } \\
\text { - Suppresses weeds } \\
\text { - Easy to multiply (high seed } \\
\text { - production) } \\
\text { - Good for intercropping }\end{array}$ & - Not edible \\
\hline $\begin{array}{l}\text { Crotalaria } \\
\text { Local name: none }\end{array}$ & $\begin{array}{l}\text { - Improves soil fertility } \\
\text { - Suppresses weeds }\end{array}$ & - Has pest problem - caterpillars \\
\hline $\begin{array}{l}\text { Tephrosia } \\
\text { Local name: Yathi fuuko } \\
\text { (medicine for mole rat) or } \\
\text { Yathirechi (medicine for fish) }\end{array}$ & $\begin{array}{l}\text { - Improves soil fertility } \\
\text { - Controls mole rat }\end{array}$ & $\begin{array}{l}\text { - Has pest that eats the pod, hence } \\
\text { poor seed formation }\end{array}$ \\
\hline $\begin{array}{l}\text { Lablab } \\
\text { Local name: none }\end{array}$ & $\begin{array}{l}\text { - Improves soil fertility } \\
\text { - Has fodder value } \\
\text { - Suppresses weeds }\end{array}$ & - Difficult to obtain seed \\
\hline $\begin{array}{l}\text { Tithonia } \\
\text { Local name: Mawuwa }\end{array}$ & $\begin{array}{l}\text { - Improves soil fertility } \\
\text { - Malaria and stomach ache } \\
\text { medicine } \\
\text { - Has pesticidal properties } \\
\text { - Fodder for goats }\end{array}$ & - It is a weed \\
\hline
\end{tabular}

Table 2 Farmer modifications and innovations to management and use of legume species

\begin{tabular}{ll}
\hline Legume species & Modification to management and use \\
Mucuna & - Attempts to cook it and eat the seed in sauce \\
& - Efforts to crush seed to make animal feed \\
- Good feed for goats, cattle and rabbits \\
Canavalia & - Used to scare off hyenas in the past, and now monkeys \\
Crotalaria & - Boundary planting around the homesteads instead of researcher-recommended \\
& - Intercropping with maize or planting as one season fallow crop \\
& - Seed put together with bean seed during storage to control bean storage pests \\
Lablab & - Seed and the leafy vegetation eaten in sauce \\
Tephrosia & - Leaves are crushed, poured into rivers and streams to catch fish \\
Tithonia & - Leaves on its effectiveness in controlling the mole rat
\end{tabular}

cover crop we can't eat' (Ramisch, personal communication).

The next stage in this adaptive research process involved the systematisation of information from the $M \& E$, detection of knowledge gaps, and the identification of potential research ques- tions during follow-up community meetings attended by the farmers, extension agents, NGO and CIAT staff. During these meetings the results of the participatory evaluation were discussed and this led to the identification of new research questions that needed to be addressed. 
Table 3 Criteria used by farmers in ranking LCC and shrub species

\begin{tabular}{|c|c|}
\hline Criteria & How farmers assess criteria \\
\hline Yield increase of crop after fallow or intercrop & - Weight of grain, bunch, fruit, etc \\
\hline Crop vigour after fallow or intercrop & $\begin{array}{l}\text { - Health } \\
\text { - Greenness of leaves }\end{array}$ \\
\hline Soil fertility increase & $\begin{array}{l}\text { - Darkening of soil colour } \\
\text { - Depth of soil increased } \\
\text { - Ease of ploughing } \\
\text { - Soil erosion control } \\
\text { - Moisture retention } \\
\text { - Time taken to cause significant fertility increase }\end{array}$ \\
\hline $\begin{array}{l}\text { Ease of germination, establishment and seed } \\
\text { production of the LLC or shrub }\end{array}$ & $\begin{array}{l}\text { - More seeds produced in a short time and viable for } \\
\text { a longer time } \\
\text { - Small seeds difficult to collect }\end{array}$ \\
\hline Multiple uses of the LLC or shrub & $\begin{array}{l}\text { - The number of other additional uses from the LCC } \\
\text { or shrub e.g. firewood, medicine, fodder, etc. }\end{array}$ \\
\hline Suitability for intercropping & $\begin{array}{l}\text { - Intercrop compatibility i.e. minimal competition of } \\
\text { the LCC or shrub with the crop }\end{array}$ \\
\hline Ability to control weeds & $\begin{array}{l}\text { - Dense canopy formation which suppresses } \\
\text { undergrowth }\end{array}$ \\
\hline Amount of biomass production & $\begin{array}{l}\text { - Number of leaves } \\
\text { - Size of leaves } \\
\text { - Ground coverage } \\
\text { - Shorter maturity period }\end{array}$ \\
\hline $\begin{array}{l}\text { Labour requirement for clearing, uprooting, } \\
\text { cutting and incorporation }\end{array}$ & $\begin{array}{l}\text { - Ease of bush clearing, uprooting, cutting stems and } \\
\text { leaves and then incorporation into the soil }\end{array}$ \\
\hline
\end{tabular}

Table 4 Overall matrix ranking of the LCCs and shrub species based on the criteria (from 21 farmer groups)

\begin{tabular}{|c|c|c|c|c|c|c|}
\hline \multirow[t]{2}{*}{ Criteria for ranking } & \multicolumn{6}{|c|}{ LCC and shrub species } \\
\hline & Mucuna & Canavalia & Crotalaria & Tithonia & Tephrosia & Lablab \\
\hline Inputs: labour, establishment ease & 2.5 & 2.0 & 4.0 & 3.0 & 5.0 & 4.5 \\
\hline Outputs: crop, soil, weed control, biomass & 1.6 & 4.0 & 3.2 & 2.2 & 5.2 & 4.6 \\
\hline Other uses: intercropping and multiple uses & 4.5 & 3.5 & 3.5 & 3.5 & 3.5 & 4.5 \\
\hline Total & 8.6 & 9.5 & 10.7 & 8.7 & 13.7 & 13.6 \\
\hline Rank & 1 & 3 & 4 & 2 & 6 & 5 \\
\hline
\end{tabular}

For example, Lablab was identified as a very promising multi-purpose legume but the variety the community had was not producing seed. As a result new photoperiod insensitive and early flowering germplasm from Australia and Africa is now undergoing on-station evaluation.

After identifying new research questions the different partners then agreed on how to address the issues. They did this by:

(1) Identifying key farmers to conduct adaptive research on behalf of the community. These farmers will establish a range of experiments, and will be responsible for monitoring the experiments and reporting back to the whole community on the results.

(2) Identifying applied research questions to be addressed by national agricultural research partners, through an array of methods from on-station research to on-farm research. For example, evaluation of early flowering $L a b$ lab accessions from Australia.

(3) Identifying strategic research questions to be addressed by CIAT, TSBF and other partner international research institutes. For 
example, primary screening of new legume cover crop species.

In so doing the M\&E has helped catalyse a number of innovation processes similar to that shown in Figure 1. Some of these are now happening with the key farmers and extension agents, not professional researchers, comprising the R\&D team shown in Figure 1.

\section{Conclusions}

The most important outputs of M\&E for the TSBF-led R\&D team was the identification of the criteria used for species selection and the farmers' innovations. Both provided essential feedback on the opportunities and constraints of the production systems of the farmers and raised many new areas of research, opportunities for the evaluation of new technologies and species, and the better targeting of existing information. The M\&E showed that farmers had a much more profound knowledge of some of the legume species than researchers originally imagined, and used this knowledge to use the legumes to fulfil a much wider range of production objectives than soil fertility replenishment or weed control. This helped researchers realise that single-use technologies, where that single use does not carry a very large benefit, have little chance of large-scale adoption. M\&E also revealed that researcher interest can motivate farmers to innovate based on their existing knowledge. Both realisations have resulted in a major rethink by researchers and partners of the methodology and approach taken and the types of research conducted in the project.

For farmers M\&E played an important role in promoting farmer-to-farmer diffusion through the organisation of exchange visits and field days. The M\&E skills that key farmers have learnt as part of the project will support local innovation when these farmers report the findings of their experiments back to their communities.

\section{IITA: Impact Pathway Evaluation of Integrated Striga Control (ISC) in Northern Nigeria}

\section{Introduction}

Striga hermonthica is a parasitic weed that attaches itself to the roots of cereals (e.g. maize, sorghum, millet and rice), diverting essential nutrients and leaving the host stunted and yielding little or no grain. The weed is the severest biological constraint to cereal production in sub-Saharan Africa, infesting almost 21 million hectares of land causing millions of dollars of damage (Sauerborn, 1991). African farmers call it 'witch' weed because it does most of its damage before it emerges from the soil.

The development phase for this project began when IITA started developing Striga control strategies (Berner et al., 1997), using largely traditional, researcher-controlled methods. The research showed that Striga control is only possible using an integrated approach that attacks Striga from several sides at the same time. The key 'best bet' in an integrated Striga control (ISC) approach is the use of a legume crop (e.g. soybean, cowpea, groundnut) that induces a high proportion of Striga seeds to germinate, which then die because they cannot parasitise legumes. This is called 'trap cropping' and the discovery that the high genetic diversity of Striga requires screening of legumes to find effective trap crops for different localities has been one of IITA's more important research contributions. To be effective, legume trap crops must be planted much more closely than farmers usually plant their legumes, and should be used together with other 'best bets' including Striga-resistant cereals, crop rotation, weeding of the Striga plants before they set seed, and improved soil fertility.

In the late 1990s, IITA started putting much more emphasis on farmer participatory research to move 'on the shelf' technologies into farmers' fields, funded in part by the British government through the Department for International Development (DfID). The start-up phase for this project began in 1999 when IITA's Agronomy Unit (AU) began working in three villages in Northern Nigeria to develop locally adapted integrated Striga control (ISC). The villages were chosen on the basis of having severe Striga problems. Two group meetings were held, first to carry out a problem consensus to rank Striga in relation to other problems, and then to design experiments with farmers to evaluate the 'best bet' options for Striga control (Schulz, 2000). In 1999, 19 farmers volunteered to establish experimental plots. An extra village and another 41 farmers joined the work in 2000 (Schulz et al., 2003). 


\section{Materials and methods}

IITA's Adoption and Impact Unit (AIU) began M\&E work in 2000 using impact pathway evaluation (IPE) (Douthwaite et al., forthcoming). IPE involved the AU and the AIU agreeing a 'map' of how the project's direct outputs - farmer participatory validation and adaptation of ISC options - might lead ultimately to the project goal of improved livelihoods for the 100 million people in Africa that are affected by Striga. Doing this helped the project realise the importance of allowing for farmer modification, and the early involvement of stakeholders who could promote the project's findings. In this way developing the impact pathway helped make eventual impact more likely.

The AIU used the 'follow the technology' (FTT) approach (Douthwaite et al., 2001b) to assess progress towards achieving the outcomes identified in the impact pathway. These outcomes were that: (1) farmers learn about ISC and this leads to, (2) changes in attitudes and perceptions, (3) experimentation and modification, and (4) adoption, although not necessarily in that order. Two additional outcomes were that: (5) adopting farmers enjoy higher and more stable incomes, and (6) the whole iterative learning process spreads to other villages. Other outcomes, such as: (7) adoption of ISC leading to sustained improvements to families' wellbeing, and (8) the take-up of ISC by local extension services, could only be assessed after several years and so were left to a future impact assessment.

The FTT approach, as its name suggests, follows the technology to identify what has happened to it. It asks the journalistic questions of who? why? what? when? where? and how? about adoption, nonadoption, modifications made, and learning processes. From October 2001 to January 2002 a survey was carried out to identify the extent to which participating farmers had increased the use of ISC on their own farms, as well as the extent of farmer-tofarmer diffusion. The experimental and expansion plots of the 60 participating farmers were mapped using a hand-held geographic positioning system (GPS). In addition, 245 expansion farmers, using one or more ISC options, were identified by asking key informants in the respective villages. The key informants included project staff and participating farmers. A data sheet was completed to record what was planted in the fields, and modifications made to the 'best bet' ISC practised in the experimental plots. From February to June 2002 an indepth survey was then carried out of a random sample of 152 of the participating and expansion farmers. The positions of the farmers' households were also mapped. The survey established farmers' existing Striga control practices and sought explanations for farmers' adoption and modification decisions, his or her understanding of ISC, and to find out where the farmer received the technologies from, and whom he or she has passed them on to. The questionnaire specifically asked whether farmers passed on any of the agronomic recommendations, e.g. close legume spacing, in addition to distributing seed.

\section{Findings and discussion}

The survey found that $90 \%$ gave weeding as their main way of controlling Striga, although few practiced it prior to the project. However, by providing farmers with an explanation of the Striga life-cycle and the need to weed it out before it flowers, the project was successful in increasing adoption to $82 \%$ (Table 5), showing that, as with the previous case study, researcher interest in local techniques can motivate farmers to use them. In contrast to weeding, although all farmers grew legumes, with soybean being the most popular, few knew that legume rotation could control Striga in cereals.

Table 5 shows the adoption of the ISC technologies. It shows large differences exist between villages, reflecting differences in farmer preference resulting from differing agro-ecological and socio-economic conditions. For example, the comparatively low adoption rate of soybean in Ankwa village compared with Kaya and Rimau was largely because there was no market for the legume.

The ISC 'best bet' options include the recommendation that farmers grow the legume trap crop as a mono-crop. This is because if cereals are grown with the legumes, then the Striga growing on that cereal can replace the seeds killed by the trap crop. Table 6 shows that over two-thirds of farmers rejected the mono-crop recommendation by continuing with their mixed cropping practices. This was initially a concern to the project. However, the 
Table 5 Percentage adoption of integrated Striga control technologies by farmers in four pilot villages in northern Nigeria

\begin{tabular}{llllrl}
\hline Technology & Ankwa & Kaya & Mahuta & Rimau & Average \\
\hline Soybean trap crop & 77 & 93 & 71 & 100 & $89 \%$ \\
Weeding of Striga & 53 & 82 & 90 & 88 & $82 \%$ \\
Rotation of legume and cereal & 41 & 84 & 94 & 83 & $81 \%$ \\
Striga-resistant maize & 6 & 41 & 55 & 48 & $42 \%$ \\
Sole crop of legume & 24 & 11 & 26 & 23 & $19 \%$ \\
Cowpea trap crop & 6 & 2 & 19 & 4 & $7 \%$ \\
Sole crop of cereal & 6 & 4 & 3 & 6 & $4 \%$ \\
Average number of technologies adopted & 2.12 & 3.20 & 3.58 & 3.50 & \\
Total & 17 & 56 & 31 & 48 & \\
\hline
\end{tabular}

$n=152$.

Table 6 Modifications made to researcher-recommended usage of integrated Striga control (ISC) options found using the mapping survey

\begin{tabular}{|c|c|c|c|c|c|}
\hline \multirow[t]{2}{*}{ Modification } & \multicolumn{4}{|c|}{ Village } & \multirow[t]{2}{*}{ Total } \\
\hline & Ankwa & Kaya & Mahuta & Rimau & \\
\hline None (mono crop) & $19(59 \%)$ & $13(10 \%)$ & $25(35 \%)$ & $48(73 \%)$ & $105(35 \%)$ \\
\hline Gicci & $1(3 \%)$ & $58(46 \%)$ & $17(24 \%)$ & $2(3 \%)$ & $78(26 \%)$ \\
\hline Strip-cropping & $0(0 \%)$ & $43(34 \%)$ & $1(1 \%)$ & $0(0 \%)$ & $44(15 \%)$ \\
\hline Intercropping & $12(38 \%)$ & $2(2 \%)$ & $4(6 \%)$ & $14(21 \%)$ & $32(11 \%)$ \\
\hline Relay-cropping & $0(0 \%)$ & $8(2 \%)$ & $35(9 \%)$ & $2(3 \%)$ & $37(13 \%)$ \\
\hline $\begin{array}{l}\text { Planting on both sides of } \\
\text { ridge }\end{array}$ & $0(0 \%)$ & $0(0 \%)$ & $1(1 \%)$ & $0(0 \%)$ & $1(0 \%)$ \\
\hline Total & $32(100 \%)$ & $126(100 \%)$ & $72(100 \%)$ & $66(100 \%)$ & $296(100 \%)$ \\
\hline
\end{tabular}

high adoption rate of weeding out Striga before it sets seed, reduces the problem of planting cereals with legumes. Most farmers have a strong preference to continue with mixed cropping because it allows them 'to harvest double' and to 'guard against crop failure'. Hence, in terms of Figure 1, 'widely adoptable' ISC will place more emphasis on weeding Striga and less on mono-cropping legumes than the best bet' ISC introduced to farmers in the startup phase.

Another finding from the M\&E was that $93 \%$ of farmers were saving at least one of the ISC seed varieties and nearly two-thirds of these farmers were giving seed, mainly soybean, on average to 2.3 other farmers. Clearly, the seed component of ISC is entering the expansion phase. Pleasingly though, of the farmers who gave seed, $85 \%$ also gave advice on how to grow the crop so as to control Striga, showing that the crop management knowledge necessary for ISC is also spreading. The mapping survey found that nonparticipating farmers were just as likely to adopt close legume spacing, indicating that knowledge as well as germplasm is spreading. In terms of Figure 1, the project has been successful in co-developing with farmers a widely adoptable integrated technology, and component technologies.

Other useful feedback from the M\&E is the pattern of adoption shown in Figure 2, which shows adoption generally clustered around the participating farmers' households. However, in all villages adoption has 'jumped' and new clusters have formed. These 'jumps' occurred through individuals promoting the technology to others. These individuals were usually farmers, but project staff also played an important role. The project is now building an extension approach that attempts to maximise farmerto-farmer diffusion by getting communities to nominate farmers to experiment on their behalf and hold regular field days to evaluate the findings. 


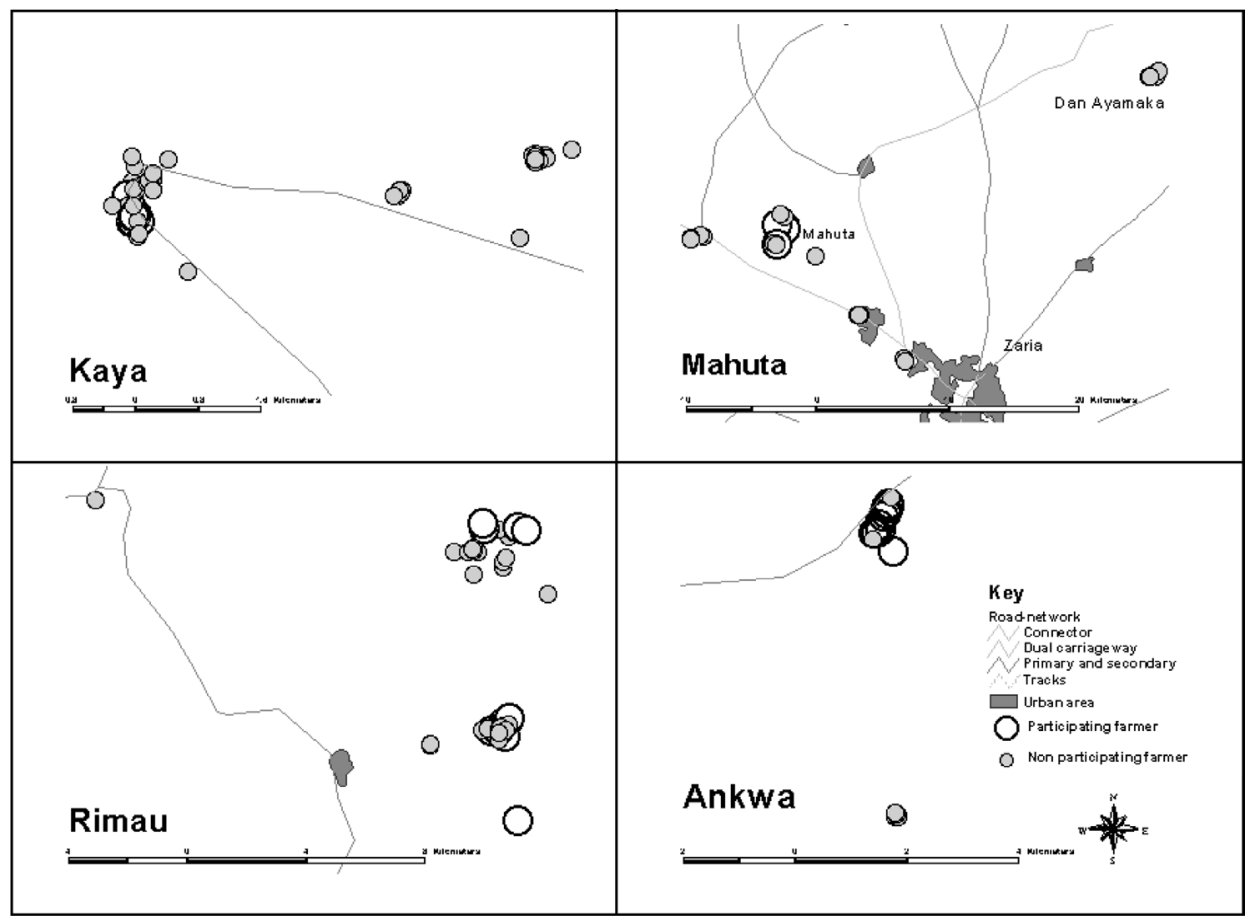

Figure 2 Adoption and spread of integrated Striga control (ISC) technologies in four villages in northern Nigeria. ISC technologies were introduced in 1999 and 2000. The map shows household adoption status in the 2002 cropping season

\section{Conclusions}

M\&E has helped give the ISC project a much clearer impact focus through the process of defining the project's impact pathway. The M\&E findings have redirected research efforts in a number of ways, which include: the incorporation of farmer innovations in the recommended basket of options; placing more emphasis on weeding out Striga and less on mono-cropping of legume trap crops; and by starting to provide the understanding of adoption processes necessary to develop an effective ISC dissemination approach.

\section{The Mother and Baby (MB) Approach to More Practical Crop Management Options for Potential Dissemination to Households in Malawi and Zimbabwe}

\section{Introduction}

In 1998, the International Crops Research Institute for the Semi-Arid Tropics (ICRISAT) and its partners in Malawi and Zimbabwe began the participatory Mother and Baby (MB) approach to develop and test soil management technologies for resource-poor farmers, particularly women farmers (Johnston et al., 2002). A mother trial was set up in three pilot sites in each country. The mother trials contained a number of 'best bet' soil management technologies and were established to validate the technologies under local conditions, as well as demonstrate them to farmers. In each village farmers were encouraged to set up baby trials under their own management and on their own land, based on one of the mother trial treatments. In terms of our map of the early adoption process shown in Figure 1, this represents the researchers' efforts to begin an adaptation phase.

\section{Materials and methods}

During the start-up phase the project invested heavily in training research and development staff from the different partner institutions in the various concepts of the participatory research process and simulation modelling. The short duration of the project meant that the problem identification and selection of best bets' occurred prior to the training in September 1999, based on the 'expert' judgement of agron- 
omists and economists which was then validated using crop simulation modelling. The 'best bet' options chosen included a range of legume intensified systems (Chamango, 2002; Twomlow et al., 2002), moderate inorganic fertiliser used alone or in combination with extra weeding (Dimes et al., 2002), and manure (Murwira \& Kudya, in press). In retrospect, 'experts' with good experience of relevant farming systems were able to select 'best bets' that were of interest to farmers, without having to first go through an identification phase with farmers.

MB trials were conducted over the 1999-2000 and 2000-2001 growing season in the six sites. Field days were carried out at different times in the growing season to solicit farmers' perceptions, using a range of participatory tools including matrix ranking. These field days were followed-up by a series of focus group discussions between March and May 2001 (Ncube \& Twomlow, 2001; Rusike \& Twomlow, unpublished field notes) in which farmers were asked to describe their cropping calendar in relation to local soil taxonomies, the labour resources used for each task, local input and output prices, the technologies they had been evaluating, and what, if anything, they had adopted or adapted beyond the experimental plots. This information was then used to construct a final adoption survey.

\section{Results and discussion}

A number of the 'best bets' gave significant yield increases compared with farmers' practice. These included the use of small quantities of fertiliser linked to weeding, legume rotations and inter-crops, and anaerobically composted manure (Dimes et al., 2002; Murwira \& Kudya, in press; Twomlow et al., 2002). About half the treatments proved better than the control, and in most the returns exceeded $100 \%$. Table 7 shows the economic, agronomic and farmers' ranking of the technologies in Malawi. The economic ranking was derived from data from focus group discussions, surveys and subsequent econometric modelling (Foti et al., 2002), while the agronomic ranking was in terms of yield performance. The differences that do exist come about for a number of reasons including resource constraints, access to input and output markets, risk and food security. The results highlighted to researchers the fact that farmers do not make decisions based on agronomic or economic considerations alone. For example, researchers initially ranked groundnut-pigeon pea and maize-Tephrosia intercrops as the best for farmers because of their high grain yields. Baby-trial farmers, however, ranked maize-pigeon pea intercrop as the best because of the grain-legume mix and the lower labour requirements. According to the babytrial farmers, the pigeon pea-groundnut rotation was attractive, but only for commercial farmers who had enough land for rotations.

An important indicator of a successful adaptation phase is evidence of farmer experimentation. The adoption survey found that this was stronger where the MB methodology was more flexible and where farmers had received 'training for transformation' in parallel (Rusike et al., 2001). The simulation modelling proved useful in simulating the performance of different combinations and amounts of fertiliser and weeding under different amounts of rainfall. This helped

Table 7 Ranking of acceptability of technology options tested in Malawi

\begin{tabular}{llll}
\hline 'Best bet' option & Agronomic & acceptability & Economic \\
\hline Unfertilised maize & 5 & 6 & Farmerc $^{\mathbf{c}}$ acceptability \\
Maize + area-specific fertiliser & 2 & 4 & 5 \\
Maize + pigeon pea & 3 & 2 & 7 \\
Maize + pigeon pea + area-specific & 1 & 3 & 2 \\
fertiliser & 6 & 5 & 6 \\
Groundnut + pigeon pea & 4 & 7 & 3 \\
Maize + Tephrosia & 7 & 1 & 4 \\
Mucuna-maize rotation & & & 1 \\
\hline
\end{tabular}

${ }^{a}$ Agronomic acceptability ranked in terms of yield performance

${ }^{b}$ Economic acceptability ranked in terms of marginal rates of return analyses

'Farmer acceptability based on seasonal matrix ranking exercises 
Table 8 Percentage of farmers reporting taking practices from trial plots to their main fields, Malawi and Zimbabwe 2000-2001

\begin{tabular}{lllll}
\hline \multirow{2}{*}{$\begin{array}{l}\text { Taken practices } \\
\text { from research } \\
\text { to fields }\end{array}$} & \multicolumn{2}{c}{ Malawi } & & \multicolumn{2}{c}{ Zimbabwe } \\
\cline { 2 - 3 } & Host & Non-host & Host & Non-host \\
\hline Yes & 64.7 & 19.8 & 76.7 & 47.3 \\
No & 35.3 & 80.2 & 23.3 & 52.7 \\
\hline
\end{tabular}

Malawi: $n=227$ (158 male, 69 female).

Zimbabwe: $n=194$ (138 male, 56 female).

answer some farmer questions and to choose worthwhile experiments based upon risk (Dimes et al., 2002).

The adoption survey of host and nonhost farmers in neighbouring villages, showed that farmers were adopting and adapting some technologies from the trial plots to their main fields. In terms of Figure 1 some of the 'best bets' have proved to be 'plausible promises' to farmers as a result of their evaluation and have moved into the adaptation phase. In both Malawi and Zimbabwe the most popular technologies were improved germplasm with accompanying management practices (Table 8).

The survey found that limited market access was often restricting the adoption of legumes to the area required to meet family consumption needs. In both countries the adoption of inorganic fertiliser 'best bets' were constrained by high fertiliser prices, even though the small doses of fertiliser (10 to $20 \mathrm{~kg}$ of $\mathrm{N} \mathrm{ha}^{-1}$ ) that the project tested with farmers, appeared to be affordable and worth the risk. These rates were typically $20 \%$ to $30 \%$ of the recommended rates, illustrating that blanket fertiliser application rates based on optimal yield response can be of little value.

The adoption survey and focus group discussions (Ncube \& Twomlow, 2001; Rusike \& Twomlow, unpublished field notes, 2002) showed that farmers' preferences and adoption of technologies depended on their access to land, labour and capital, and the gender of the household head influenced access to these resources (Tables 9 and 10). In both countries male-headed households tended to have access to labour and draft animals, but little cash, so adopted legume rotations, perceived to require more land and small doses of fertiliser. De facto female-headed households often had access to cash remittances from their husbands, but had little labour, and hence favoured new cereal varieties together with the 'best bet' fertiliser, pit-composted manure and weeding treatments. Land constraint faced by women-headed households meant they favoured intercropping compared with crop rotation favoured by their male colleagues. The poorer resourced de jure femaleheaded households could not afford fertiliser and so were less likely to adopt new cereal varieties, preferring instead technologies that required little cash or labour, such as heapcovered composted manure, reduced tillage, and dead-level contours and modified-tied ridges for in-field water harvesting. This new understanding has been aided by combining farmer participatory research with both biophysical and econometric modelling to assess the riskiness and profitability of proposed interventions. In this way the simulation

Table 9 Practices taken by farmers into main fields, by gender of household head, Malawi, 2000-2001

\begin{tabular}{llcl}
\hline Practice & $\begin{array}{l}\text { Status of household heads } \\
\text { Male-headed } \\
(\boldsymbol{n}=\mathbf{1 5 8})\end{array}$ & $\begin{array}{l}\text { Female-headed } \\
(\boldsymbol{n}=\mathbf{6 9})\end{array}$ & $\begin{array}{c}\text { All } \\
(\boldsymbol{n}=\mathbf{2 2 7})\end{array}$ \\
\hline New maize varieties & 5.2 & 14.3 & 7.6 \\
Groundnut rotation and intercrops & 17.5 & 22.9 & 19 \\
Soybean rotation and intercrops & 12.3 & 17.1 & 13.7 \\
Tephrosia rotation and intercrops & 5.1 & 8.6 & 6.1 \\
Pigeon pea rotation and intercrops & 17.5 & 11.4 & 15.9 \\
Mucuna rotation and intercrops & 11.3 & 2.9 & 9.1 \\
Incorporating crop residues & 10.3 & 5.7 & 6.1 \\
Crop rotations & 7.2 & 2.9 & 0.8 \\
Intercrops & 0 & 2.9 & 6.8 \\
Spacing, plant population & 6.2 & 8.6 & 1.6 \\
Early plant, small fertilisers & 2 & 0 & 4.5 \\
Kraal/compost manure & 5.2 & 2.9 & \\
\hline
\end{tabular}


Table 10 Practices taken by farmers into main fields, by gender of household head, Zimbabwe, 2000-2001

\begin{tabular}{|c|c|c|c|c|}
\hline \multirow[t]{2}{*}{ Practice } & \multicolumn{4}{|c|}{$\%$ uptake } \\
\hline & $\begin{array}{l}\text { Male-headed } \\
(n=138)\end{array}$ & $\begin{array}{l}\text { De facto female } \\
(n=42)\end{array}$ & $\begin{array}{l}\text { De jure female } \\
(n=14)\end{array}$ & $\begin{array}{l}\text { All } \\
(n=194)\end{array}$ \\
\hline New cereal varieties & 31.5 & 37.8 & 16.6 & 32.3 \\
\hline Legumes rotations/intercrops & 20.8 & 10.2 & 13.3 & 18.7 \\
\hline Seed priming, planting methods, spacing & 16.1 & 20.5 & 16.6 & 16.8 \\
\hline Small fertiliser/weeding/manure & 8.6 & 13.8 & 0 & 7.7 \\
\hline Treated manure & 16.7 & 30.9 & 26.7 & 19.9 \\
\hline Water harvesting & 14.8 & 0 & 20 & 13.6 \\
\hline Reduced tillage/compost & 0.6 & 0 & 6.6 & 1.4 \\
\hline
\end{tabular}

modelling further added to researcher understanding of factors affecting farmer decisionmaking.

\section{Conclusions and lessons learned}

The adoption survey, field days and focus group discussions helped researchers appreciate that farmers' access to resources and climatic risk affects farmers' decision-making in addition to economic and agronomic performance most commonly considered by 'expert' opinion. The work has helped show ICRISAT and its partners that future work in soil fertility management should take into account the high cost of inorganic fertiliser, the effects of climatic risk, poor market for legumes and the realisation that different types of household have different access to resources and hence favour different technology options. The work has also shown that the way field research is carried out, in terms of whether farmers can experiment on their own, numbers and types of field days held, and whether training to build the capacity of farmers as experimenters is provided, can greatly affect adoption, adaptation and eventual impact. Providing farmers training in leadership can also affect adoption.

The case study has also shown the value of modelling as an aid to M\&E and learning. Crop simulation modelling can help researchers further develop their understanding, and can help farmers and researchers decide on which treatments are most likely to fit local conditions and farmer preferences, thus speeding up the experimentation and leaning process.

\section{Synthesis}

\section{Model of the innovation process}

The three case studies provided evidence to confirm the innovation systems view of innovation as a complex process, characterised by interactions among agents and processes, strong feedback loops and intrinsic randomness. Indeed, a common theme through the case studies was that the M\&E provided information that confounded 'experts' expectations, showed reality to be more complex than expected, and that farmers generally had a more profound understanding of that complexity than researchers imagined. The Uganda and Nigeria case studies show that farmers were actively modifying the technologies in ways that could not be predicted. Different modifications were made in different areas, reflecting differences in local conditions. In Uganda, farmers sought alternative uses for the LCC and BT technologies that would increase the return on their investment in labour and land. In Nigeria, farmers sought to find compromises between the 'best bet' agronomic practice and what fitted their own systems. In all three case studies researchers learnt from these modifications and adapted their thinking and recommendations accordingly.

This experimentation and modification, and the fact that it helped improved the adoptability of the respective case study technologies, largely confirms the conceptual map of the development and adoption process shown in Figure 1. The fact that in all three case studies the 'best bets' were researcher-defined suggests that there is a role for researchers in introducing 
new ideas into communities, on the condition that the researchers have a good understanding of the local farming systems, and that farmers are supported in adapting the initial idea. Purely farmer-led technology development is less likely to bring new ideas into the community because researchers have a deeper knowledge and understanding of new technical options, while farmers are concerned with their current problems and have few human and financial resources to search for and adapt novel solutions. On the other hand, the Uganda and Nigeria case studies showed that researcher interest, combined with better understanding, can motivate farmers to take their existing knowledge and technologies more seriously. The case studies generally confirm findings elsewhere (e.g. Rogers, 1995) that farmers are more likely to adopt technologies that require little change to existing practice.

\section{The contribution of M\&E to learning and adaptive management}

The case studies clearly show the importance of various M\&E approaches in providing feedback that leads to adaptive management based on learning from the feedback. In the Zimbabwe and Malawi case study researchers learnt that farmers select technologies based on resources available to that household and perceptions of risk, in addition to agronomic and economic factors generally used by scientists. The Zimbabwe and Malawi case study also showed that gender of the household head can affect access to resources and technology choice. This understanding has help shape ICRISAT's priorities in soil fertility research in sub-Saharan Africa. In Nigeria, M\&E findings showed that many farmers were adopting legume trap crops to control Striga, but not the concept of sole cropping, preferring to continue to grow cereals with the trap crop. In response, the project will place more emphasis on encouraging farmers to weed out the Striga growing on the cereal before it sets seed.

Several tools proved useful in facilitating learning and the innovation processes. These included matrix ranking of 'best bets', field days and developing a common understanding of the impact pathway. Field days proved useful not only for researcher learning but also for farmers to learn from each other. The Nigeria case study showed how this learning can lead to technologies spreading to other villages. Indeed, one conclusion from this work is that perhaps more emphasis needs to be put on encouraging farmer $M \& E$ through field days, exchange visits, etc. The Zimbabwe and Malawi work showed the value of using crop simulation modelling to develop and test understanding, as well as to speed up the learning process through developing and testing scenarios together with farmers.

\section{The contribution of M\&E to ex post impact assessment}

In each of the three case studies, the projects worked with a wide range of agents, including farmers, NGOs, extension workers and national research institutes. The technologies that enter the expansion phase, shown in Figure 1, represent a synthesis of a number of stakeholders' knowledge and innovation. The implication is that any future impact resulting from these technologies cannot be individually attributed. Rather, in accordance with the 'innovation systems' view, the innovation has been the result of the interaction of a network of actors. M\&E can help the plausibility of ex post impact assessment by giving a good description of the early adoption process, and the roles of the different stakeholders involved. Such documentation would be an invaluable starting point to ex post impact assessment some years after.

\section{Conclusions}

The case studies show that NRM research aimed at sustainably improving the well-being of small-holder farmers in Africa is complex, and that $M \& E$ is an essential tool in coping with this complexity. M\&E proved useful in helping researchers gain a better understanding of the systems in which they worked, and adjusted their activities and research outputs accordingly. Much of this insight came through identifying farmer innovations, which also proved a source of improvements to the respective technologies. Together, better research understanding and iterative improvements made eventual widespread impact more likely. Farmer M\&E also proved useful in facili- 
tating adoption and should be given equal priority to M\&E aimed at furthering researcher understanding. The understanding and documentation of the early adoption process provided by M\&E can provide a foundation for plausible ex post impact assessment. However, despite its uses the types of M\&E described in this paper are not yet mainstream practice in international agricultural research, and will only become so by continuing demonstrations of usefulness, and by a wider acceptance by researchers of the 'innovation systems' view of the innovation process as opposed to more commonly held linear ones.

\section{Acknowledgements}

An earlier version of this paper was prepared on behalf of the CGIAR's integrated natural resource management (INRM) community of practice on impact assessment http:// groups.yahoo.com/group/inrm_impact, and presented at the Fourth INRM Task Force Workshop, 16-19 September 2002, International Center for Research in Dry Areas (ICARDA), Aleppo, Syria. The authors would like to thank the three JASL reviewers as well as the editorin-chief Prof Jules Pretty and Dr Doug White of CIAT for their comments and suggestions that helped make this a better paper.

\section{Correspondence}

Any correspondence should be directed to Dr Boru Douthwaite, Technology Policy Analyst, International Center for Tropical Agriculture (CIAT), AA 6713, Cali, Colombia (Boru@douthwaite.net).

\section{References}

Alston, J.M., Norton, G.W. and Pardey, P.G. (1995) Science under Scarcity. New York: Cornell University Press.

Berner, D.K, Winslow, M.D., Awad, A.E., Cardwell, K.F., Mohan Raj, D.R. and Kim, S.K. (1997) Striga Research Methods - A Manual (2nd edn). Ibadan: International Institute of Tropical Agriculture.

Biggs S.D. (1989) A multiple source model of innovation of agricultural research and technology promotion. ODI Agricultural Administration Network Paper: 6. London: Overseas Development Institute.

Chamango, A.M.Z. (2002) Improving grain yield of smallholder cropping systems: A farmer partici- patory research (FPR) approach with legumes for soil fertility improvement in central Malawi. 7th Eastern and Southern Africa Regional Maize Conference and Symposium on Low-Nitrogen and Drought Tolerant-Maize, 11-15 February 2002. Nairobi: International Maize and Wheat Improvement Center (CIMMYT) and Kenya Agricultural Research Institute (KARI).

Chambers, R. and Jiggins, J. (1986) Agricultural research for resource poor farmers: A parsimonious paradigm. Discussion Paper 220, Brighton: Institute of Development Studies.

Clark N. (1995) Interactive nature of knowledge systems: Some implications for the Third World. Science and Policy 22, 249-258.

Dimes, J., Muza, L., Malunga, G. and Snapp, S. (2002) Trade-offs between investments in nitrogen and weeding: On-farm experimentation and simulation analysis in Malawi and Zimbabwe. 7th Eastern and Southern Africa Regional Maize Conference and Symposium on Low-Nitrogen and Drought Tolerant-Maize, 11-15 February 2002. Nairobi: International Maize and Wheat Improvement Center (CIMMYT) and Kenya Agricultural Research Institute (KARI).

Douthwaite, B. (2002) Enabling Innovation: A Practical Guide to Understanding and Fostering Technological Change. London: Zed Books.

Douthwaite, B. Keatinge, J.D.H. and Park, J.R. (2001a) Why promising technologies fail: The neglected role of user innovation during adoption. Research Policy 30 (5), 819-836

Douthwaite, B., de Haan, N.C. Manyong, V. and Keatinge, J.D.H. (2001b) Blending 'hard' and 'soft' science: The 'follow-the-technology' approach to catalyzing and evaluating technology change. Conservation Ecology 5 (2). On-line documents at URL http://www.consecol.org/vol5/iss2/art13 (2 April, 2002).

Douthwaite, B. Keatinge, J.D.H. and Park, J.R. (2002) Evolutionary learning selection: A model for planning, implementing and evaluating participatory technology development. Agricultural Systems 72 (2), 109-131.

Douthwaite, B., Kuby, T., van de Fliert, E. and Schulz, S. (forthcoming) Bridging the attribution gap: An evaluation approach for achieving and attributing impact. Agricultural Systems.

Ekboir, J. (forthcoming) Why impact analysis should not be used for research evaluation and what the alternatives are. Agricultural Systems.

Foti, R., Rusike, J. and Dimes, J. (2002) Risk diversification opportunities through legumes in smallholder farming systems in the semi-arid areas of Zimbabwe. Paper presented at the Soil Fert Net Conference: Grain Legumes and Green Manures for Soil Fertility in Southern Africa: Taking Stock of Progress. Leopard Rock Hotel, Vumba, Zimbabwe, 8-11 October 2002. Harare: International Maize and Wheat Improvement Center (CIMMYT).

Horton, D. (1998) Disciplinary roots and branches of evaluation: Some lessons from agricultural research. Knowledge and Policy 10 (4), 31-66.

Johnson, N., Lilja, N. and Ashby, J. (2001) Charac- 
terising and measuring the effects of user participation in natural resource management research: Analysis of benefits and costs of research in three case studies. PRGA Working Document No. 17. Cali: International Center for Tropical Agriculture (CIAT).

Kaufman, S. (1995) At Home in the Universe: The Search for the Laws of Self-Organization and Complexity. New York: Oxford University Press.

Murwira, H.K. and Kudya, T.L. (in press) Economics of heap and pit storage of cattle manure. Tropical Science.

Ncube, B. and Twomlow, S. (2001) Soil fertility management - integrating farmers and researchers priorities. Proceedings of a Planning Workshop, 18-19 September 2000, Masvingo, Zimbabwe. Bulawayo: International Crops Research Institute for the SemiArid Tropics (ICRISAT) and Harare: International Maize and Wheat Improvement Center (CIMMYT).

Nelson, R. (ed.) (1993) National Innovation Systems, A Comparative Analysis. New York: Oxford University Press.

Organisation for Economic Co-operation and Development (OECD) (1999) Managing National Innovation Systems. Paris: OECD.

Probst, K. (2002) Participatory Monitoring and Evaluation: A Promising Concept in Participatory Research? Lessons from Two Case Studies in Honduras. Weikersheim: Margraf Publishers.

Rhoades, R.E. and Booth, R.H. (1982) Farmer-backto-farmer: A model for generating acceptable agricultural technology. Agricultural Administration 11, 127-137.

Rogers, E.M. (1995) Diffusion of Innovations (3rd edn), rev. edn of Communication of Innovations. New York: The Free Press.

Rosenberg, N. (1982) Inside the Black Box: Technology and Economics. Cambridge: Cambridge University Press.

Rusike J, Twomlow, S., Freeman, H. and Heinrich, G.M. (2001) Impact indicators for comparing participatory research approaches to promote soil fertility in semi-arid southern Africa. Paper presented at Integrated Natural Resource Management Work- shop, 28-31 August 2001, Cali: International Center for Tropical Agriculture (CIAT).

Ruthenberg, H. (1985) Innovation Policy for Small Farmers in the Tropics. In H.E. Jahnke (ed.). Oxford: Clarendon Press.

Rycroft, R.W. and Kash, D.E. (1999) The Complexity Challenge: Technological Innovation for the 21st Century. Science, Technology and the International Political Economy Series. New York: Cassell.

Sauerborn, J. (1991) The economic importance of phytoparasites Orobranche and Striga. In J.K. Ransom, L.J. Musselman, A.D. Wosham and C. Parker (eds) Proceedings of the 5th International Symposium on Parasitic Weeds, 24-30 June 1991. Nairobi: International Maize and Wheat Improvement Center (CIMMYT).

Sayer, J. and Campbell, B. (2001) Integrated natural resource management research to integrate productivity enhancement, environmental protection and human development. Conservation Ecology 5 (2) On-line documents at URL http://www.conse col.org/vol5/iss2/ (2 April, 2002).

Schulz, S. (2000) Farmer participation in research and development: The problem census and solving technique. Research Guide No. 57. Ibadan: International Institute of Tropical Agriculture.

Schulz, S., Hussaini, M.A., Kling, J., Berner, D.K. and Ikie, F.O. (2003) Evaluation of integrated Striga hermonthica control technologies under farmer management. Experimental Agriculture 39, 1-10.

Sechrest, L., Stewart, M., Stickle, T.R., and Sidani, S. (1996) Effective and Persuasive Case Studies. Tuscon: Jaguar Graphics.

Sumberg, J. (2002) The logic of fodder legumes in Africa. Food Policy 27, 285-300.

Twomlow, S.J., Rusike, J. and Snapp, S.S. (2002) Biophysical or economic performance which reflects farmer choice of legume 'Best Bets' in Malawi. 7th Eastern and Southern Africa Regional Maize Conference and Symposium on Low-Nitrogen and Drought Tolerant-Maize, 11-15th February 2002. Nairobi: International Maize and Wheat Improvement Center (CIMMYT) and Kenya Agricultural Research Institute (KARI). 